\author{
N.Yu. Filonenko ${ }^{1,3}$, A. N. Galdina ${ }^{2}$, A.I. Babachenko ${ }^{3}$, G.A. Kononenko ${ }^{3}$
}

\title{
Structural State and Thermodynamic Stability of Fe-B-C Alloys
}

\author{
${ }^{1}$ State Institution "Dnipropetrovsk Medical Academy of Health Ministry of Ukraine”, Dnipro, Ukraine natph2016@gmail.com \\ ${ }^{2}$ Oles Honchar Dnipro National University, Dnipro, Ukraine, Dnipro, Ukraine, alexandragaldina@gmail.com \\ ${ }^{3}$ Z.I. Nekrasov Iron and Steel Institute of National Academy of Sciences of Ukraine, Dnipro, Ukraine, \\ A_Babachenko@i.ua,perlit@ua.fm
}

\begin{abstract}
The studies were performed for the specimens of Fe-B-C alloys with boron content of $0.005-7.0 \mathrm{wt} . \%$ and carbon content of $0.4-5.5$ wt. $\%$, the rest was iron. From the data of microstructure analysis, X-ray structural and differential thermal analyses, was determined that the primary phases formed as a result of crystallization of $\mathrm{Fe}$ B-C system alloys, depending on content of boron and carbon in the alloy.

As a result of the experiment carried out in this work, the phase composition and phase transformations occurring in the alloys are investigated and the liquidus surface is constructed; it is shown that the point with minimum temperature of $1375 \mathrm{~K}$ at the liquidus surface is observed at boron content of $2.9 \mathrm{wt} . \%$ and carbon content of 1.3 wt. \%.

For the first time, considering the contribution of the first degree approximation of high-temperature expansion of thermodynamic potential into the Gibbs energy of Fe-B-C melt, was obtained that the surface of thermodynamic stability of Fe-B-C melt, depending on temperature and content of boron and carbon in the alloy. The findings show that in order to obtain the homogeneous Fe-B-C melt, which does not contain microinhomogeneous structures in the form of short-range microregions, it is necessary to perform overheating more than to $150 \mathrm{~K}$.
\end{abstract}

Key words: $\mathrm{Fe}-\mathrm{B}-\mathrm{C}$ system alloys, $\mathrm{Fe}_{2} \mathrm{~B}$ boride, $\mathrm{Fe}_{3}(\mathrm{CB})$ boron cementite, eutectics, thermodynamic stability of the melt.

Article acted received 12.10.2019; accepted for publication 15.12.2019.

\section{Introduction}

It is known that the processes occurring in the alloy melts affect the crystallization process and the phase composition of the alloys. To predict these processes, the region of thermodynamic stability of the melt should be determined. Fe-B-C alloys have good physical properties such as hardness and wear resistance [1-3].

Considerable attention is paid to study of the phase composition of alloys of the Fe-B-C system [4-8]. The authors of work [6] note that when boron content is 1.0$2.5 \mathrm{wt} . \%$ the formation of primary phase of $\gamma$-iron occurs at the temperature of $1422 \mathrm{~K}$ in the Fe-B-C alloy after crystallization. This is in agreement with the results of the authors [5]. With an increase in boron content of the alloy up to $3.8 \mathrm{wt} \%$ after crystallization the primary phase is $\mathrm{Fe}_{2} \mathrm{~B}$ boride.

The liquidus surface of the Fe-B-C alloys was first obtained by G. Tammann; the ternary eutectic point with boron content of $2.9 \mathrm{wt} . \%$ and carbon content of $1.5 \mathrm{wt} . \%$ at the temperature of $1383 \mathrm{~K}$ was mapped at this surface. According to the authors of Ref. [8] the eutectic point occurs at boron content of $2.6 \mathrm{wt} . \%$ and carbon content of $1.5 \mathrm{wt} . \%$ at $1339 \mathrm{~K}$, and in [9] it is stated that when boron content is $1.5 \mathrm{wt} . \%$ and carbon content is $2.5 \mathrm{wt} . \%$ at $1402 \mathrm{~K}$, there is minimum of temperature, boron and carbon content at the liquidus surface.

Thus, there is no consensus on the liquidus surface temperature depending on boron and carbon content for $\mathrm{Fe}_{-} \mathrm{Fe}_{2} \mathrm{~B}-\mathrm{Fe}_{3}(\mathrm{CB})$ alloys. No data are currently available on the homogeneity and thermodynamic stability of the Fe-B-C melts.

The purpose of this paper is to investigate the liquidus temperature depending on content of boron and carbon in the alloy and to determine the homogeneity 
limit of the melt of $\mathrm{Fe}-\mathrm{Fe}_{2} \mathrm{~B}-\mathrm{Fe}_{3}(\mathrm{CB})$ system.

\section{Materials and methods}

The investigation was carried out for the specimens with boron content of 0.005-7.0 wt. \% and carbon content of $0.4-5.5 \mathrm{wt} \%$, the rest was iron. To obtain $\mathrm{Fe}-$ B-C alloys, we used such constituents: carbonyl iron (with iron content of 99.95 wt.\%), amorphous boron (with boron content of 97.5 wt.\%), graphite (with carbon content of $99.96 \mathrm{wt} . \%$ ). Smelting of specimens was performed in a Tammann furnace in alundum crucibles in argon atmosphere. The cooling rate of the alloys was $20 \mathrm{~K} / \mathrm{min}$. To determine the chemical composition of alloys, chemical and spectral analysis was used [10]. To ascertain the peculiarities of phase transformations in the Fe-B-C system alloys, differential thermal analysis of 72 specimens was performed by means of derivatograph.

The phase composition of alloys was studied by method of X-ray microanalysis by means of JSM-6490 microscope with ASID-4D scanning head and "Link Systems 860" software energy-dispersive X-ray microanalyser, and by means of optical microscope "Neophot-21". The X-ray electron probe analysis was carried out using internal standards. The X-ray and X-ray diffraction analyses were performed with DRON-3 diffractometer in monochromated $\mathrm{Fe}-\mathrm{K}_{\alpha}$ radiation.

\section{Results and discussion}

Investigation of the liquidus temperature in alloys of Fe-B-C system and primary phases depending on boron and carbon content shows that at boron content of 3.0 wt. $\%$ and carbon content of $0.65 \mathrm{wt} . \%$ after crystallization we have primary crystals of iron and two eutectics: $\gamma-\mathrm{Fe}+\mathrm{Fe}_{2} \mathrm{~B}$ and $\gamma-\mathrm{Fe}+\mathrm{Fe}_{3}(\mathrm{CB})$ (Fig. 1a).

In the process of crystallization, the formation of primary $\gamma$-Fe crystals occurs within the temperature range of $1417-1420 \mathrm{~K}$. In the range of $1397-\mathrm{K}$, the formation of eutectics $\gamma-\mathrm{Fe}+\mathrm{Fe}_{2} \mathrm{~B}$ takes place, and in the interval of $1393-1396 \mathrm{~K}$ the eutectics $\gamma-\mathrm{Fe}+\mathrm{Fe}_{3}(\mathrm{CB})$ appears. The transformation $\gamma$-Fe $\leftrightarrow \alpha$-Fe occurs at $996 \mathrm{~K}$ (Fig. 1c).

The study of alloys with boron content of 0.3 5.5 wt.\% and carbon content of 2.1-6.6 wt.\% shows that primary crystals in the crystallization of melts are crystals of boron cementite $\mathrm{Fe}_{3}(\mathrm{CB})$. During aftercooling, the formation of eutectics $\gamma-\mathrm{Fe}+\mathrm{Fe}_{3}(\mathrm{CB})$ with lamellar morphology is observed (Fig. 2a).

The formation of primary crystals of boron cementite $\mathrm{Fe}_{3}(\mathrm{CB})$ occurs in the temperature range of 1431-1427 $\mathrm{K}$, and in the interval of $1403-1387 \mathrm{~K}$ the eutectics $\gamma$ $\mathrm{Fe}+\mathrm{Fe}_{3}(\mathrm{CB})$ forms with a significant thermal effect. The transformation $\gamma$-Fe $\leftrightarrow \alpha$-Fe is detected at the temperature of $973 \mathrm{~K}$.

For alloys with boron content of 2.2-8.8wt.\% and carbon content of $0.5-2.1 \mathrm{wt} . \%$ in the process of crystallization, the formation of primary crystals of $\mathrm{Fe}_{2} \mathrm{~B}$ iron boride takes place. In certain areas of structure the
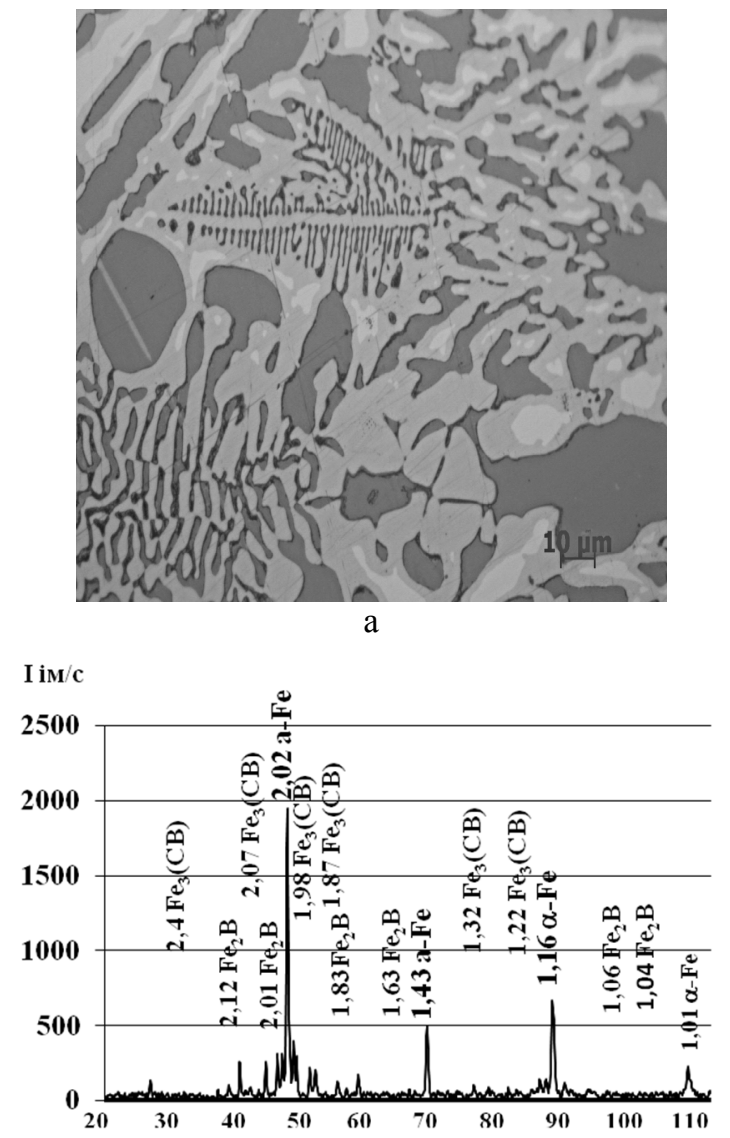

b

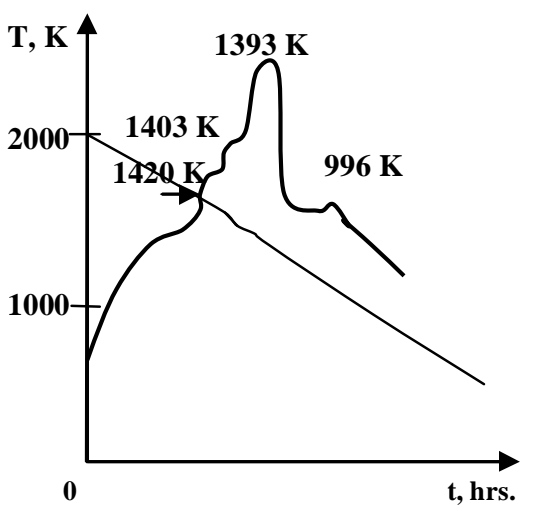

Fig. 1. For alloy with boron content of $3.0 \mathrm{wt} . \%$ and carbon content of $0.65 \mathrm{wt} . \%$ : a) microstructure, $\times 800$, b) diffractogram, c) curve of differential thermal analysis.

primary borides surrounded by shell consisting of $\mathrm{Fe}_{3}(\mathrm{BC})$ boron cementite and eutectics $\alpha$-Fe+Fe $\mathrm{Fe}_{3}(\mathrm{BC})$ with morphology like to that of boride eutectics $(\alpha-$ $\mathrm{Fe}+\mathrm{Fe}_{2} \mathrm{~B}$ ) are observed (Fig. 3a).

According to results of differential thermal analysis primary crystals of boride are formed from the melt in the temperature range of 1533-1498 $\mathrm{K}$ in boron cementite environment formed during peritectic transformation $\mathrm{L}+\mathrm{Fe}_{2} \mathrm{~B} \rightarrow \mathrm{Fe}_{3}(\mathrm{CB})$ in the temperature range of $1388-1433 \mathrm{~K}$; the eutectics $\gamma$ $\mathrm{Fe}+\mathrm{Fe}_{3}(\mathrm{CB})$ is formed at the constant temperature of $1399 \mathrm{~K}$, which indicates possibility of four-phase 

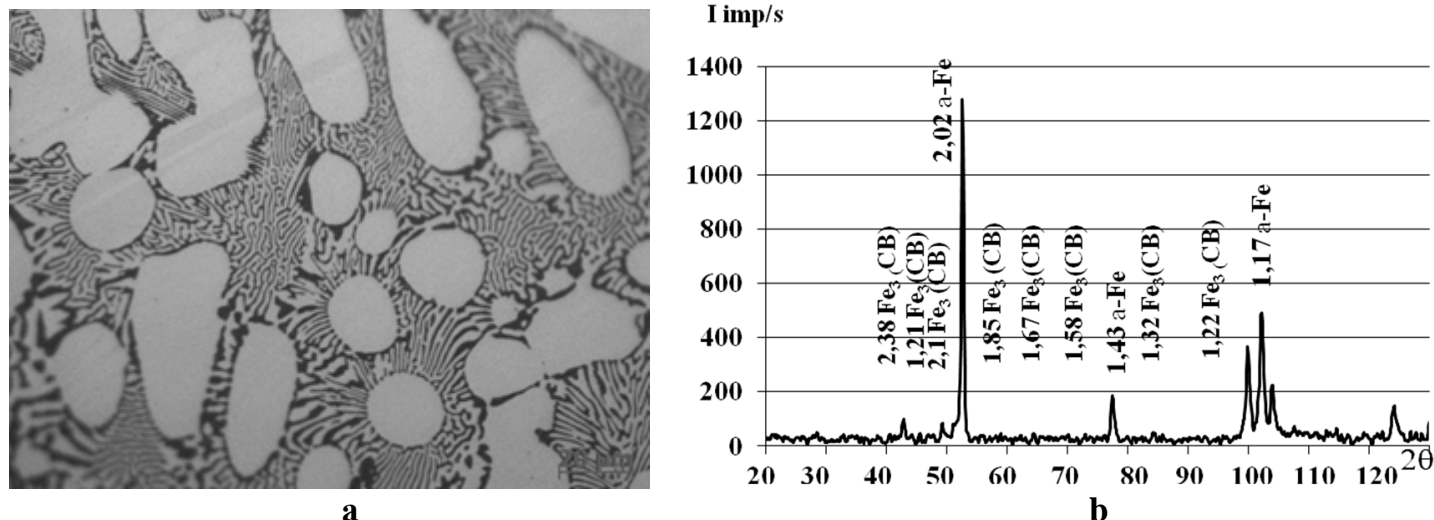

$\mathbf{a}$

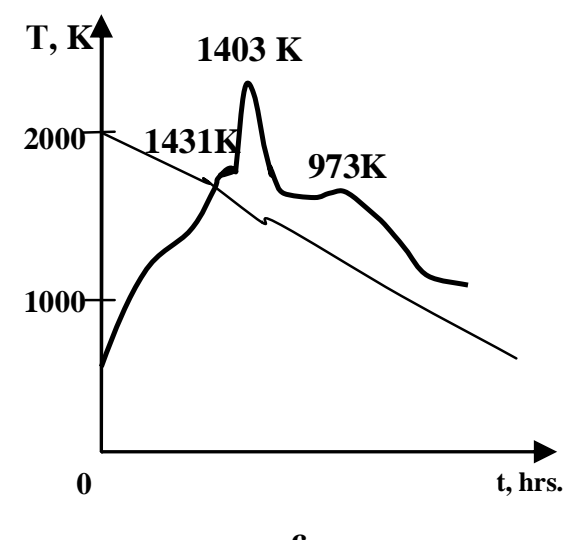

Fig. 2. For alloy with boron content of 3.43 wt. $\%$ and carbon content of 2.25 wt. $\%$ : a) microstructure, $\times 800$, b) diffractogram, в) curve of differential thermal analysis.

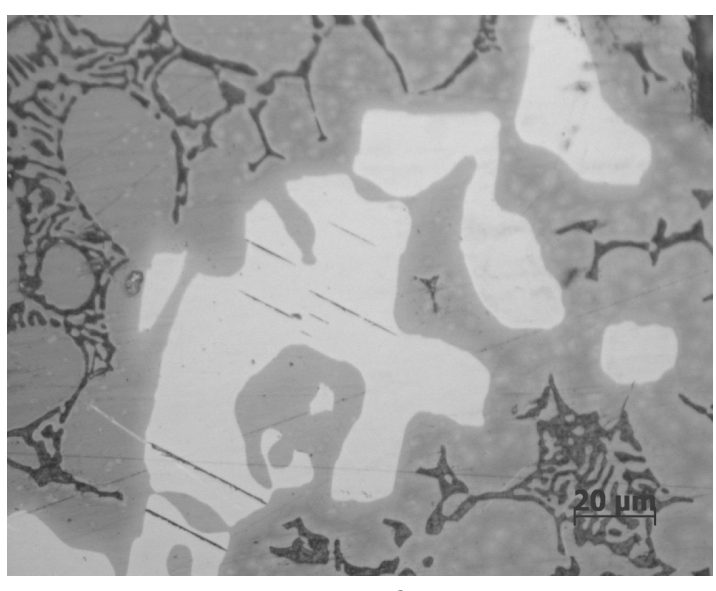

a

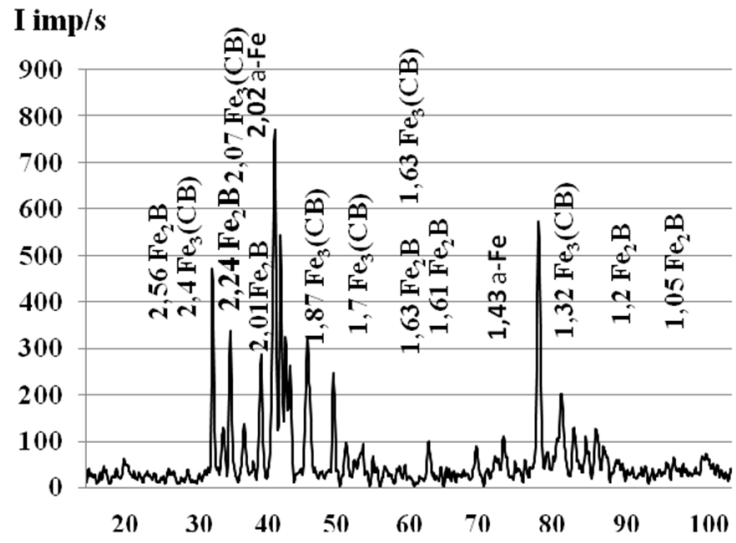

b

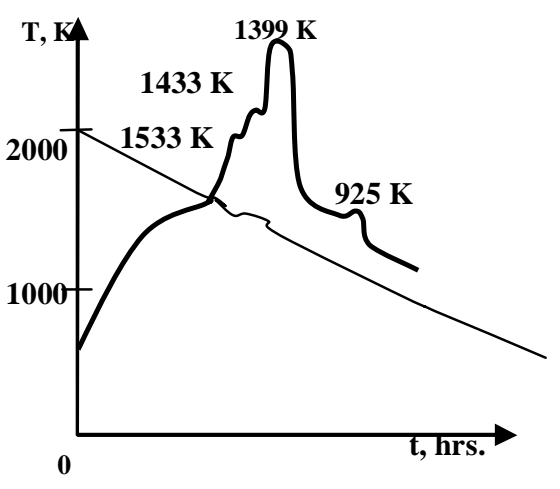

c

Fig. 3. For alloy with boron content of $2.5 \mathrm{wt} \% \%$ and carbon content of $4.0 \mathrm{wt} . \%$ : a) microstructure, $\times 800$, б) diffractogram, в) curve of differential thermal analysis. 
transformation $\mathrm{L}+\mathrm{Fe}_{2} \mathrm{~B} \rightarrow \gamma-\mathrm{Fe}+\mathrm{Fe}_{3}(\mathrm{CB})$ and the transformation $\gamma$-Fe↔ $a-\mathrm{Fe}$ at $925 \mathrm{~K}$ (Fig. 3c).

The outcomes show that Fe-B-C system alloys are characterized by low liquidus temperature compared to binary Fe-B and Fe-C alloys. This is in good agreement with the results of other authors [11-12].

Investigation of microstructure, $\mathrm{X}$-ray diffraction and differential thermal analyses of 72 specimens enables to construct the liquidus surface for alloys of Fe-B-C system (Fig. 4).

One of the important factors affecting the formation of alloys structure under cooling is determination of the liquid stability that is the temperature when the homogeneity of the liquid is observed and there are no microcrystalline formations.

The Gibbs energy of the phase is known to be a function of independent variables $G=G\left(p, T, x_{i}\right)$, where $p$ is pressure, $T$ is temperature, $x_{i}$ is weight content of elements, $i=1,2,3\left(x_{1}=x_{\mathrm{Fe}}, x_{2}=x_{\mathrm{B}}, x_{3}=x_{\mathrm{C}}\right)$. Provided that there are no external force and change in pressure ( $p=$ const $)$ the total differential of Gibbs energy is [13]:

$$
d G=d U-d(T S)+d(p V)=-S d T+\sum_{i=1,2,3} \mu_{i} d x_{i},
$$

where $U$ is internal energy.

Correspondingly, entropy of the system equals
$S=-\left(\frac{\partial G}{\partial T}\right)_{x_{1} x_{2} x_{3}}, \quad$ and chemical potential is $\mu_{i}=\left(\frac{\partial G}{\partial x_{i}}\right)_{T}$

To determine the stability of the phase, let us find the variation of Gibbs energy:

$$
\delta G=\sum_{n=1}^{\infty} \frac{1}{n !}\left[\delta T \frac{\partial}{\partial T}+\delta x_{1} \frac{\partial}{\partial x_{1}}+\delta x_{2} \frac{\partial}{\partial x_{2}}+\delta x_{3} \frac{\partial}{\partial x_{3}}\right]^{n} G
$$

The general condition of phase stability by Gibbs is that arbitrary variations of the internal energy and external parameters of the system should not cause both reversible and irreversible processes in the system (to keep the system in equilibrium), so they must be such that

$\delta U-T \delta S+p \delta V-\mu_{1} \delta x_{1}-\mu_{2} \delta x_{2}-\mu_{3} \delta x_{3}>0$,

considering the relation between internal energy and free Gibbs energy $U=G+T S-p V$ and the fact that $\delta S=-\delta\left(\frac{\partial G}{\partial T}\right)_{x_{1} x_{2} x_{3}}=-\left(\frac{\partial \delta G}{\partial T}\right)_{x_{11} x_{2} x_{3}}$.

Let us expand the Gibbs energy as a power series in small parameters $\delta T, \delta x_{1}, \delta x_{2}$ and $\delta x_{3}(1)$ :

$$
\begin{aligned}
& \delta G=-S \delta T+\mu_{1} \delta x_{1}+\mu_{2} \delta x_{2}+\mu_{3} \delta x_{3}+\frac{1}{2}\left(\left(-\frac{\partial S}{\partial T}\right)_{x_{1} x_{2} x_{3}} \delta T^{2}+2\left(\frac{\partial \mu_{1}}{\partial T}\right)_{x_{1} x_{2} x_{3}} \delta T \delta x_{1}+\right. \\
& +2\left(\frac{\partial \mu_{2}}{\partial T}\right)_{x_{1} x_{2} x_{3}} \delta T \delta x_{2}+2\left(\frac{\partial \mu_{3}}{\partial T}\right)_{x_{1} x_{2} x_{3}} \delta T \delta x_{3}+\left(\frac{\partial \mu_{1}}{\partial x_{1}}\right)_{T x_{2} x_{3}} \delta x_{1}^{2}+\left(\frac{\partial \mu_{2}}{\partial x_{2}}\right)_{T x_{1} x_{3}} \delta x_{2}^{2}+ \\
& \left.+\left(\frac{\partial \mu_{2}}{\partial x_{3}}\right)_{T x_{1} x_{2}} \delta x_{3}^{2}++2\left(\frac{\partial \mu_{2}}{\partial x_{1}}\right)_{T x_{2}} \delta x_{1} \delta x_{2}+2\left(\frac{\partial \mu_{2}}{\partial x_{3}}\right)_{T x_{2}} \delta x_{2} \delta x_{3}+2\left(\frac{\partial \mu_{1}}{\partial x_{3}}\right)_{T x_{2}} \delta x_{1} \delta x_{3}\right]+\cdots
\end{aligned}
$$

To determine the derivative $\left(\frac{\partial \delta G}{\partial T}\right)_{x_{1} x_{2} x_{3}}$ we consider only the first and second order terms in expansion (3), as well as equality of mixed derivatives:

$$
\begin{gathered}
-\left(\frac{\partial S}{\partial x_{1}}\right)_{T x_{2} x_{3}}=\left(\frac{\partial \mu_{1}}{\partial T}\right)_{x_{1} x_{2} x_{3}}, \quad-\left(\frac{\partial S}{\partial x_{2}}\right)_{T x_{1} x_{31}}=\left(\frac{\partial \mu_{2}}{\partial T}\right)_{x_{1} x_{2} x_{3}},-\left(\frac{\partial S}{\partial x_{3}}\right)_{T x_{1} x_{2}}=\left(\frac{\partial \mu_{2}}{\partial T}\right)_{x_{1} x_{2} x_{3}} \\
\left(\frac{\partial \mu_{1}}{\partial x_{2}}\right)_{x_{1} x_{3} T}=\left(\frac{\partial \mu_{2}}{\partial x_{1}}\right)_{x_{2} x_{3} T},\left(\frac{\partial \mu_{1}}{\partial x_{3}}\right)_{x_{1} x_{2} T}=\left(\frac{\partial \mu_{3}}{\partial x_{1}}\right)_{x_{2} x_{3} T},\left(\frac{\partial \mu_{2}}{\partial x_{3}}\right)_{x_{1} x_{2} T}=\left(\frac{\partial \mu_{3}}{\partial x_{2}}\right)_{x_{1} x_{3} T} .
\end{gathered}
$$

Inserting Eqs. (3), (4) in the stability condition (2) and considering the second order terms, we obtain the inequality:

$$
\begin{gathered}
\left(\frac{\partial S}{\partial T}\right)_{x_{1} x_{2} x_{3}} \delta T^{2}+\left(\frac{\partial \mu_{1}}{\partial x_{1}}\right)_{T x_{2} x_{3}} \delta x_{1}^{2}+\left(\frac{\partial \mu_{2}}{\partial x_{2}}\right)_{T x_{1} x_{3}} \delta x_{2}^{2}+\left(\frac{\partial \mu_{3}}{\partial x_{3}}\right)_{x_{1} x_{2} T} \delta x_{3}^{2}+2\left(\frac{\partial \mu_{1}}{\partial T}\right)_{x_{1} x_{2} x_{3}} \delta T \delta x_{1}+ \\
+2\left(\frac{\partial \mu_{2}}{\partial T}\right)_{x_{1} x_{2} x_{3}} \delta T \delta x_{2}+2\left(\frac{\partial \mu_{3}}{\partial T}\right)_{x_{1} x_{2} x_{3}} \delta T \delta x_{3}+2\left(\frac{\partial \mu_{2}}{\partial x_{1}}\right)_{T x_{2} x_{3}} \delta x_{1} \delta x_{2}+2\left(\frac{\partial \mu_{2}}{\partial x_{3}}\right)_{T x_{1} x_{2}} \delta x_{2} \delta x_{3}+ \\
+2\left(\frac{\partial \mu_{1}}{\partial x_{3}}\right)_{T x_{2} x_{1}} \delta x_{1} \delta x_{3} \geq 0
\end{gathered}
$$


If we have a quadratic form $a_{11} x_{1}^{2}+a_{12} x_{1} x_{2}+a_{13} x_{1} x_{3}+\ldots+a_{n n} x_{n}^{2} \geq 0$, then it will be positive when the determinant consisting of its coefficients and all principal minors (Sylvester's criterion) will be positive:

$$
D=\left|\begin{array}{llll}
\left(\frac{\partial S}{\partial T}\right)_{x_{1} x_{2} x_{3}} & \left(\frac{\partial \mu_{1}}{\partial T}\right)_{x_{1} x_{2} x_{3}} & \left(\frac{\partial \mu_{2}}{\partial T}\right)_{x_{1} x_{2} x_{3}} & \left(\frac{\partial \mu_{3}}{\partial T}\right)_{x_{1} x_{2} x_{3}} \\
\left(\frac{\partial \mu_{1}}{\partial T}\right)_{x_{1} x_{2} x_{3}} & \left(\frac{\partial \mu_{1}}{\partial x_{1}}\right)_{T x_{2} x_{3}} & \left(\frac{\partial \mu_{1}}{\partial x_{2}}\right)_{T x_{3} x_{1}} & \left(\frac{\partial \mu_{1}}{\partial x_{3}}\right)_{T x_{1} x_{2}} \\
\left(\frac{\partial \mu_{2}}{\partial T}\right)_{x_{1} x_{2} x_{3}} & \left(\frac{\partial \mu_{1}}{\partial x_{2}}\right)_{T x_{1} x_{3}} & \left(\frac{\partial \mu_{2}}{\partial x_{2}}\right)_{T x_{1} x_{3}} & \left(\frac{\partial \mu_{2}}{\partial x_{3}}\right)_{T x_{1} x_{2}} \\
\left(\frac{\partial \mu_{3}}{\partial T}\right)_{x_{1} x_{2} x_{3}} & \left(\frac{\partial \mu_{1}}{\partial x_{3}}\right)_{T x_{2} x_{1}} & \left(\frac{\partial \mu_{2}}{\partial x_{3}}\right)_{T x_{1} x_{2}} & \left(\frac{\partial \mu_{3}}{\partial x_{3}}\right)_{T x_{2} x_{1}}
\end{array}\right|
$$

The case $D=0$ was first defined by J. W. Gibbs as a critical state of matter [14]. At supercritical transitions the determinant and coefficients of stability pass through finite minima that correspond to the growth of fluctuations. The locus of these minima is low-stability curve. It should be emphasized that for different coefficients of stability, the curves of lowered stability may differ. This is why the curve of lowered stability for $D$ [15], which includes all equilibrium characteristics of the system and therefore best describes its stability, is used as a basis. The threshold case of supercritical transitions when fluctuations in the system reach the maximum level, the determinant and coefficients of stability pass zero minima, is the critical state. So, let us consider when $d D=0$.

When calculating thermodynamic functions of the phases for the high-temperature region, we take into consideration the first degree approximation of hightemperature expansion for thermodynamic potential of the melt in the form of infinite series in powers of $1 / T$ [16] and obtain the temperature dependence of Gibbs energy:

$$
\begin{aligned}
& G_{m}=\sum_{i=1}^{3} x_{i} G_{i}^{0}+R T \sum_{i=1}^{3} x_{i} \ln x_{i}+ \\
& +\sum_{i \neq \mathrm{j}} x_{i} x_{j} L_{i j}-\sum_{i \neq \mathrm{j}} \frac{L_{i j}^{2} x_{i}^{2} x_{j}^{2}}{2 Z T R}
\end{aligned},
$$

where $G_{i}^{0}$ is Gibbs energy for pure components $(\mathrm{J} / \mathrm{mol})$, $R$ is universal gas constant $(R=8.31 \mathrm{~J} /(\mathrm{mol} \cdot \mathrm{K})), T$ is temperature $(\mathrm{K}), L_{i j}$ is interaction energy of the components $(\mathrm{J} / \mathrm{mol}), \mathrm{Z}$ is coordination number, which equals $Z=10$ for liquid [17]. The summation is over all $i$ and $j$ providing $i \neq j$.

To calculate the numerical values of thermodynamic functions of the melt, we used data for pure components $G_{1}^{0}, G_{2}^{0}$ from $[18,19]$ and interaction energy between components 1 and $2 L_{12}=a+b T+c T \ln T$ (constants $a, b, c)$, between components 2 and 3 $L_{23}=d+e T+f T \ln T$ (constants $d, e, f$ ), between components 1 and $3 \quad L_{13}=k+l T+m T \ln T$ (constants $k, l, m$ ) from [20-22].

To determine the stability of the melt, the condition $d D=0$ should be fulfilled:

$$
d D=\left(\frac{\partial D}{\partial T}\right)_{x_{1} x_{2} x_{3}} d T+\left(\frac{\partial D}{\partial x_{1}}\right)_{T x_{2} x_{3}} d x_{1}+\left(\frac{\partial D}{\partial x_{2}}\right)_{T x_{1} x_{3}} d x_{2}+\left(\frac{\partial D}{\partial x_{3}}\right)_{T x_{1} x_{2}} d x_{3}=0
$$

The condition (6) holds when

$$
\left(\frac{\partial D}{\partial T}\right)_{x_{1} x_{2} x_{3}}=0, \quad\left(\frac{\partial D}{\partial x_{1}}\right)_{T x_{2} x_{3}}=0, \quad\left(\frac{\partial D}{\partial x_{2}}\right)_{T x_{1} x_{3}}=0, \quad\left(\frac{\partial D}{\partial x_{3}}\right)_{T x_{1} x_{2}} d x_{3}=0 .
$$

The solution of system of equations (7) is shown in Fig. 4.

The experimental results obtained in this work make it possible to construct the liquidus surface, and calculated data enable to plot the surface of thermodynamic stability of the melt (Fig. 4). The liquidus surface of the Fe-B-C alloys was first obtained by G. Tammann; the ternary eutectic point with boron 


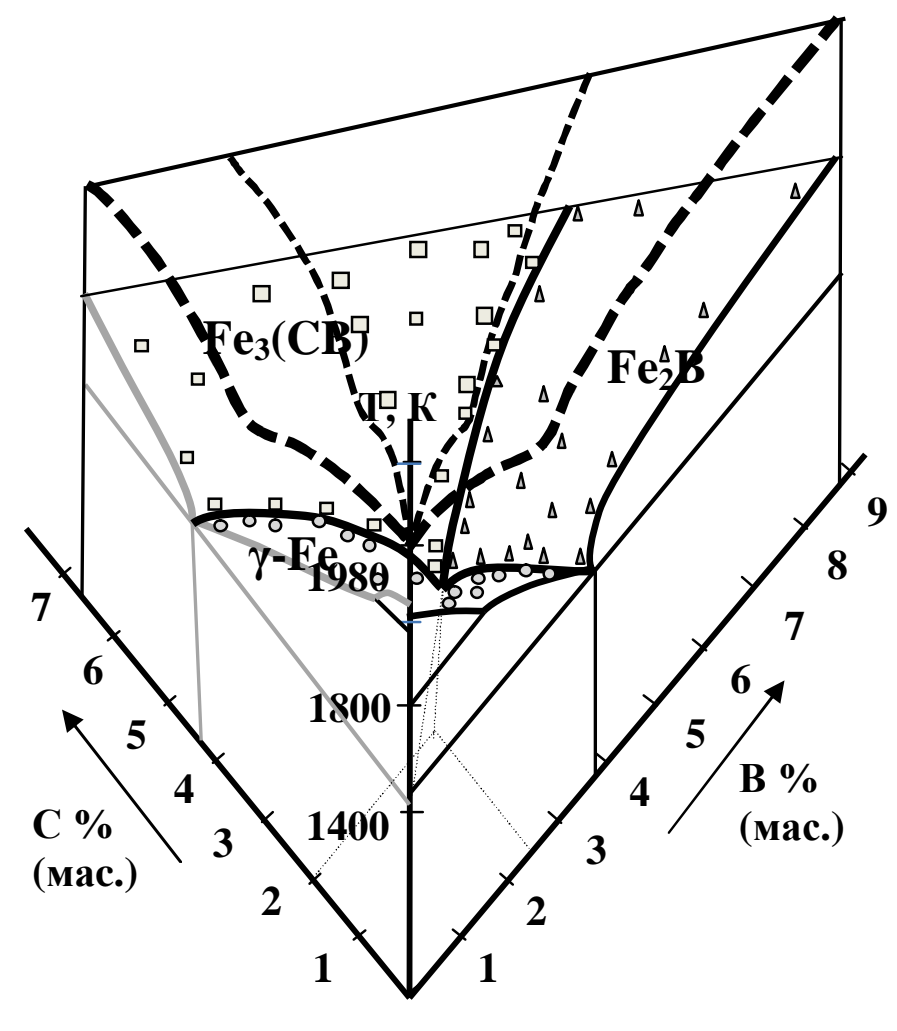

Fe

Fig. 4. State diagram of Fe-B-C system $\left(\square-\mathrm{Fe}_{3}(\mathrm{CB}), \Delta-\mathrm{Fe}_{2} \mathrm{~B}, \bigcirc-\gamma-\mathrm{Fe}\right)$ and surface of thermodynamic stability of the melt ( - Fe-B diagram, - - Fe-C diagram, - eutectic lines, $-\quad$ - surface of thermodynamic stability of the Fe-B-C melt).

content of 2.9 wt. $\%$ and carbon content of $1.5 \mathrm{wt} . \%$ at $1383 \mathrm{~K}$ was mapped on this surface. The ternary eutectic point is the intersection of lines of monovariant binary eutectics.

The liquidus surface study presented in [9] showed that the ternary eutectic point occurs at boron content of $1.5 \mathrm{wt} . \%$ and carbon content of $2.5 \mathrm{wt} . \%$ and at the temperature of $1402 \mathrm{~K}$.

The results obtained in this investigation show that at the liquidus surface in Fe-B-C alloys there is minimum at boron content of $2.9 \mathrm{wt} . \%$ and carbon content of $1.3 \mathrm{wt} . \%$ at $1375 \mathrm{~K}$. The outcomes are in agreement with data given in [4], where it is stated that the solidus temperature is $1400 \mathrm{~K}$.

The process of primary phase's formation has a great effect on the structural state and phase transformations in the alloy. There are currently no known data on determining and investigating the homogeneity of the melt of Fe-B-C alloys. According to the findings, to obtain the homogeneous Fe-B-C melt, which does not contain a microheterogeneous structure in the form of short-range microareas where primary crystals is $\gamma$-Fe phase, it is necessary to perform overheating more than to $150 \mathrm{~K}$. For the alloys with boron and carbon content close to the quasi-binary cross-section, one need to perform the overheating of alloy more than to $200 \mathrm{~K}$ to obtain the homogeneous melt.

\section{Conclusions}

In this work the phase composition and phase transformation occurring in the alloys with boron content of 0.005-7.0 wt.\% and carbon content of 0.4-5.5 wt.\% (the rest is iron) is studied. It is shown that formation of primary phases $\gamma-\mathrm{Fe}, \mathrm{Fe}_{2} \mathrm{~B}$ and $\mathrm{Fe}_{3}(\mathrm{CB})$ takes place depending on boron and carbon content in alloys.

The liquidus surface is plotted experimentally for $\mathrm{Fe}$ $\mathrm{B}-\mathrm{C}$ alloys in the concentrarion range of $0-8.85 \mathrm{wt} . \%$ boron and 0-6.65 wt.\% carbon and it is shown that the ternary eutectic point occurs at the liquidus surface in the alloys of Fe-B-C systems with boron content of 2.9 wt.\% and carbon content of $1.3 \mathrm{wt} \%$ at the temperature of $1375 \mathrm{~K}$.

In the paper, for the first time, considering the contribution of the first degree approximation of hightemperature expansion of thermodynamic potential into the Gibbs energy of the Fe-B-C melt, we obtain the dependence of temperature of thermodynamic stability of the melt on boron and carbon content in the alloy and plot the surface of concentration anomaly without microcomplexes in the melt. According to the findings, it is necessary to perform the overheating more than to 150 $\mathrm{K}$ to obtain the homogeneous melt of $\mathrm{Fe}-\mathrm{BC}$, which does not contain microheterogeneous structure in the form of short-order microareas, where primary crystals is $\gamma$-Fe 
phase. For $\mathrm{Fe}_{2} \mathrm{~B}$ and $\mathrm{Fe}_{3}(\mathrm{CB})$ phases the melt should be overheated more than to $200 \mathrm{~K}$.

The work was performed within the specific project "Resurs" KC063.18 "Development of chemical composition and technological decisions for the manufacture of railway wheels for different application and their maintainability" of the NAS of Ukraine.
Filonenko N.Yu. - PhD, Associate Professor, Department of Medical Biological Physics and Informatics, Senior Researcher, Department of Deformation-Thermal Processing of Structural Steels;

Galdina O.M. - Ph.D., Senior Researcher, Department of Theoretical Physics;

Babachenko A.I. - Doctor of Technical Sciences, Senior Researcher, Head of the Department of DeformationHeat Treatment of Structural Steels; director;

Kononenko G.A. - Candidate of Science (Engineering), Senior Researcher, Department of Deformation-Heat Treatment of Structural Steels.

[1] Fu Hanguang, Alloy Nonferrous Metals 9, 113 (2005).

[2] Zhao Guorong, Li Zhenhua, Liu Meihong, He Zhengyuan, Alloy Hot Working Technology 15, 113 (2011).

[3] Song Xu, Fu Han, Yang Jun, Transactions of Materials and Heat Treatment 1, 164 (2008).

[4] Ayako Sudo, Tsuyoshi Nishi, Noriko Shirasu, Masahide Takano and Masaki Kurata, Journal of Nuclear Science and Technology 52(10) (2015) (doi:10.1080/00223131.2015.1016465).

[5] Xiangyi Ren, Hanguang Fu, Jiandong Xing, Yongwei Yang, Shuli Tang, Journal of Materials Research 32(16), 3078 (2017) (doi: 10.1557/jmr.2017.304).

[6] P. Sang, H.Fu,Y.Qu, C. Wang, Y. Lei, Materials Science \& Engineering Technology 46(9), 962 (2015) (doi: 10.1002/mawe.201500397).

[7] Zhifu Huang; Jiandong Xing; Shengqiang Ma; Yimin Gao; Ming Zheng; Liqiu Sun, Engineering Materials 732, 59 (2017) (doi:10.4028/www.scientific.net/KEM.732.59).

[8] I.M. Spiridonova, S.B. Pilayeva, E.B.Syxovaya, E.B. Zinkovski Visnik Dnipropetrovskogo nacionalnogo universitetu. Serija. fizika. 8, 32 (2002).

[9] Eberhard Schürmann, Clausthal, und Shao-Xiong Li, Jilin Jahrgang 121 (1985).

[10] S.V. Tverdokhlebova Visnik Dnipropetrovskogo nacionalnogo universitetu. Serija. fizika. Radioelektronika, 14(12/1) 100 (2007).

[11] H. Ohtani, M. Hasebe, K. Ishida, T. Nishizawa, Calculation Trans. Iron Steel Inst. Jpn. 281043 (1988).

[12] Takafumi Hibino, Teruo Bitoh, Journal of Alloys and Compounds 707, 82 (2017) (doi:10.1016/j.jallcom.2016.12.060).

[13] V.V. Sychev, The differentialequations of the termodynamics (Moscow, Vyisshaya shkola, 1991).

[14] J.W. Gibbs, Termodinamicheskie raboty. (Moscow: Gostehizdat, 1950).

[15] A.N. Galdina, Visnik Dnipropetrovskogo nacionalnogo universitetu. Serija fizika. Radioelektronika 14(12/1), 68 (2007).

[16] L.A. Zhirifalko, Statistical mechanics of solids (Oxford, University Press, 2000).

[17] M.P. Shaskolskaya, Crystallography (Moscow, Vyisshaya shkola, 1984).

[18] R.A. Roble, D.R. Waldbaum, Thermodynamic Properties of Minerals and Related Substances at $298.15^{\circ}$ K $\left(25.0^{\circ} \mathrm{C}\right)$ and One Atmosphere (1.013 Bars) Pressure and at Higher Temperatures (Orton memorial library the OHIO State University 155 S. Oval Drive, 1970).

[19] A.T. Dinsdale, SGTE data for pure elements (NPL Materials Centre, Division of Industry and Innovation, National Physical Laboratory, Teddington, Middlesex, TW11 0LW, UK, 1991).

[20] M. Palumbo, G. Cacciamani, E. Bosco, M. Baricco, Intermetallics 11, 1293 (2003) (doi:10.1016/S09669795(03)00171-7).

[21] Van Rompaey T., K.C. Kumar, P. Wollants, Journal of Alloys and Compounds 334, 173 (2002).

[22] Takahiro Miki, Kenjirou Tsujita1, Shiro Ban-Ya, Mitsutaka Hino, Computer Coupling of Phase Diagrams and Thermochemistry 30, 449 (2006) (doi:10.1016/j.calphad.2006.07.001). 


\title{
Н.Ю. Філоненко ${ }^{1,3}$, О.М. Галдіна ${ }^{2}$, О. І. Бабаченко ${ }^{3}$, Г. А. Кононенко ${ }^{3}$
}

\section{Структурний стан та термодинамічна стійкість сплавів системи Fe-B-C}

\author{
${ }^{1}$ Д3 «Дніпропетровська державна медична академія МО3 України» 49044, Україна, м. Дніпро, вул. \\ ВолодимираВернадського, 9, natph2016@ gmail.com \\ ${ }^{2}$ Дніпровський національний університет імені Олеся Гончара72 49010, Україна, м. Дніпро, пр. Гагаріна, E-таіl: \\ alexandragaldina@gmail.com \\ ${ }^{3}$ Інститут чорно їметалургї ім. 3. І. Некрасова НАН Украйни (ІЧМ НАНУ) \\ 49107, Україна, м. Дніпро, пл. Ак. Стародубова К. Ф., 1 A_Babachenko@i.ua, perlit@ua.fm
}

Дослідження здійснювали на зразках сплавів системи Fe-B-C вмістом бору 0,005-7,0 \% (мас.) та карбону 0,4 - 5,5\% (мас.), інше залізо. За результатами мікростурктурного, рентгеноструктурного та диференційного термічного аналізів визначені первинні фази, що утворюються в результаті кристалізації сплавів системи $\mathrm{Fe}-$ В-С в залежності від вмісту бору та карбону в сплаві.

За результатами експерименту, проведеного в даній роботі досліджено фазовий склад та фазові перетворення, що відбуваються в сплавах та побудована побудована поверхня ліквідусу та показано, що точка, яка має мінімальну температуру 1375 К на поверхні ліквідусу спостерігали при вмісті бору 2,9 \% (мас.) та карбону $1,3 \%$ (мас.).

Вперше із врахуванням внеску в енергії Гіббса розплаву Fe-B-C першого ступеня наближення високотемпературного розвинення термодинамічного потенціалу отримано поверхню термодинамічної стійкості розплаву Fe-B-C в залежності від температури та вмісту бору та карбону в сплаві. Отримані в роботі результати показали, що для досягнення однорідного розплаву $\mathrm{Fe}-\mathrm{B}-\mathrm{C}$, що не містить мікронеоднородної структури у вигляді мікроділянок з ближнім порядком необхідно виконати перегрів більш ніж на $150 \mathrm{~K}$.

Ключові слова: сплави системи $\mathrm{Fe}-\mathrm{B}-\mathrm{C}$, борид $\mathrm{Fe}_{2} \mathrm{~B}$, бороцементит $\mathrm{Fe}_{3}(\mathrm{CB})$, евтектика, термодинамічна стійкість розплаву. 